\title{
Aplikasi E-Test “That Quiz” sebagai Digitalisasi Keterampilan Pembelajaran Abad 21 di Sekolah Indonesia Bangkok
}

\author{
Kuncahyono $^{1]}$, Beti Istanti Suwandayani ${ }^{2]}$, Abdurrohman Muzakki ${ }^{3]}$ \\ Universitas Muhammadiyah Malang \\ E-mail: ${ }^{1]}$ kuncahyono@umm.ac.id, \\ ${ }^{2]}$ beti@umm.ac.id, \\ ${ }^{3]}$ abdurrohmanmuzakki@gmail.com
}

\begin{abstract}
Abstrak
Internet of things merupakan bagian dari pemanfaatan E-learning yang dapat digunakan sebagai strategi pembelajaran dengan memanfaatkan fasilitas teknologi informasi dan komunikasi virtual. Bentuk pemanfaatan teknologi tersebut salah satunya dapat dimanfaatkan dalam pembelajaran tematik dan penilaian berbasis online. Berdasarkan hasil analisis situasi di Sekolah Indonesia (SIB) KBRI Bangkok didapatkan hasil dalam kegiatan tersebut berdasarkan pengamatan menunjukkan bahwa masih ditemukan adanya beberapa guru yang masih memerlukan pembaharuan tentang pembelajaran berbasis teknologi informasi, sekitar $45 \%$ peserta didik kurang aktif, penilaian pembelajaran masih bersifat konvensional dan belum diintegrasikan dalam teknologi internet. Tujuan penelitian ini untuk mengetahui kontribusi media kuis interaktif that quiz sebagai inovasi penilaian berbasis online menggunakan internet of things. Metode yang digunakan dalam penelitian ini menggunakan metode deskriptif kualitatif. Teknik pengumpulan data dalam penelitian ini menggunakan wawancara, observasi, dan pemberian angket. Penelitian ini menghasilkan pembelajaran sekaligus penilaian berbasis kuis online menggunakan aplikasi that quiz. Pembelajaran dilakukan secara daring dengan memanfaatkan internet of things. Guru-guru menghasilkan produk akun quiz online dengan aplikasi open source that quiz. Hasil pelaksanaan pembelajaran yang dilaksanakan guru menggunakan aplikasi that quiz bahwa guru lebih mudah mengakses materi secara ringkas dan cepat. Guru lebih mudah melaksanakan penilaian dan kontrol siswa secara langsung. Akses pembelajaran dan penilaian dapat dikontrol secara terbuka oleh orang tua. Peningkatan kompetensi digital skill karena guru terlibat langsung dalam proses perencanaan, kegiatan pembelajaran dan evaluasi pembelajaran. Guru hendaknya menambah materi dalam kuis online. Guru dapat meningkatkan varian jenis soal-soal penilaian pada ranah lain.
\end{abstract}

Kata Kunci: That Quiz, Internet of Things, Digital skill

\section{Application of the "That Quiz" E-Test as a Digitalization of 21st Century Learning Skills at the Indonesian School in Bangkok}

\begin{abstract}
Internet of things is part of the use of E-learning that can be used as a learning strategy by utilizing information and virtual communication technology facilities. One of the forms of technology utilization can be utilized in thematic learning and online-based assessment. Based on the results of a situation analysis at the Indonesian Embassy in Bangkok, the
\end{abstract}


results of the activity were based on observations showing that there were still some teachers who still needed updates on information technology-based learning, about $45 \%$ of students were less active, the assessment of learning was still conventional and not yet integrated in internet technology. The purpose of this study was to determine the contribution of interactive quiz media that quizzes as an online-based assessment innovation using the internet of things. The method used in this study uses descriptive qualitative methods. Data collection techniques in this study used interviews, observation, and questionnaires. This research resulted in learning as well as online quiz-based assessment using that quiz application. Learning is done online by utilizing the internet of things. Teachers produce online quiz account products with an open-source application quiz. The results of the implementation of learning carried out by the teacher using the application that quiz that teachers more easily access the material in a concise and fast manner. It is easier for teachers to carry out student assessments and control directly. Access to learning and assessment can be controlled openly by parents. Improved digital skills competency because teachers are directly involved in the planning process, learning activities and learning evaluation. Teachers should add material to the online quiz. The teacher can improve the various types of assessment questions in other domains.

Keywords: That Quiz, Internet Of Things, Digital skills

\section{PENDAHULUAN}

Pada abad 21 ini, perkembangan teknologi menjadi hal terpenting yang mempengaruhi seluruh sendi kehidupan. Tidak terkecuali juga perkembangan para generasi muda yang merupakan aset terbesar suatu bangsa, termasuk bangsa Indonesia (Izzah, 2018). Hal ini dipertegas menurut (Pendidikan \& Indonesia, 2004) dalam buku "seri pendidikan orang tua: mendidik anak di era digital" menyatakan bahwa generasi muda di Indonesia termasuk generasi digital. Definisi generasi digital adalah generasi yang lahir setelah adopsi teknologi digital. Dalam perkembangannya, generasi digital di Indonesia tampak pada penggunaan internet. Menurut hasil riset yang dilakukan oleh Asosiasi Penyelenggara Jasa Internet Indonesia (APJII) bersama dengan Pusat Kajian Komunikasi (Puskakom) Universitas Indonesia, total jumlah pengguna Internet di Indonesia per awal 2015 adalah 88,1 juta orang (Prestianta,
2016). Akan tetapi, sesuai dengan riset yang dilansir oleh wearesocial.sg pada tahun 2017 tercatat ada sebanyak 132 juta pengguna internet di Indonesia dan angka ini tumbuh sebanyak 51 persen dalam kurun waktu satu tahun.

Perkembangan generasi digital di atas memberikan pengaruh secara langsung pada berbagai sendi kehidupan termasuk dalam hal pendidikan bagi generasi digital (Indonesia \& Study, 2017). Hal ini juga sejalan menurut (Suwandayani et al., 2019) bahwa pendidikan yang berkualitas sangat penting untuk menyiapka peserta didik dalam persaiangan di era globalisasi. Berkembangnya peralatan digital dan akses akan informasi dalam bentuk digital mempunyai tantangan sekaligus peluang. Salah satu kehawatiran yang muncul adalah jumlah generasi muda yang mengakses internet sangat besar, yaitu kurang lebih 70 juta orang.

Mereka menghabiskan waktu mereka untuk berinternet, baik melalui telepon genggam, komputer personal, 
atau laptop, mendekati 5 jam per harinya. Tingginya penetrasi internet bagi generasi muda tentu meresahkan banyak pihak dan fakta menunjukkan bahwa data akses anak Indonesia terhadap konten berbau pornografi per hari rata-rata mencapai 25 ribu orang (Tarma \& Hasanah, 2017). Belum lagi perilaku berinternet yang tidak sehat, ditunjukkan dengan menyebarnya berita atau informasi hoaks, ujaran kebencian, dan intoleransi di media sosial. Hal-hal tersebut tentunya menjadi tantangan besar bagi dunia pendidikan, yang mempunyai tanggung jawab dan peran penting dalam mempersiapkan generasi abad ke-21, generasi yang memiliki kompetensi digital.

Dalam penerapannya secara langsung maupun tidak menuntut peserta didik untuk beraktivitas tanpa dibatasi ruang dan waktu. Selain itu juga akan berpengaruh pada $4 \mathrm{C}$ para calon Guru SD ini. Adapun 4C Critical Thinking and Problem Solving (berpikir kritis dan menyelesaikan

masalah), Creativity (kreativitas), Comm unication Skills (kemampuan berkomunikasi), dan Ability to Work Collaboratively (kemampuan untuk bekerja sama) merupakan kompetensi yang harus dimiliki mahasiswa pada abad 21 ini. (Ashim et al., 2019) Melalui pembelajaran berbasis mobile learning dan penguasaan komunikasi matematika harapannya mampu menciptakan kualitas pendidikan yang lebih baik, guru dan siswa mampu mengikuti perkembangan teknologi, serta mampu meningkatkan kemampuan 4C di Era Disrupsi

Salah satu sistem pendidikan terbesar di dunia yaitu sistem pendidikan Indonesia yang meliputi sekitar 30 juta peserta didik, 200 ribu lembaga pendidikan, dan 4 juta tenaga pendidik. Perubahan pola pembelajaran dari era sebelum digital dan era digital menjadi salah satu keharusan untuk menyiapkan generasi digital yang berkualitas. P21 (Partnership for 21st Century Learning) mengembangkan framework pembelajaran di abad 21 yang menuntut mahasiswa untuk memiliki keterampilan, pengetahuan dan kemampuan dibidang teknologi, media dan informasi, keterampilan pembelajaran dan inovasi serta keterampilan hidup dan karir (P21, 2015). Framework ini juga menjelaskan tentang keterampilan, pengetahuan dan keahlian yang harus dikuasai agar mahasiswa dapat sukses dalam kehidupan dan pekerjaannya.

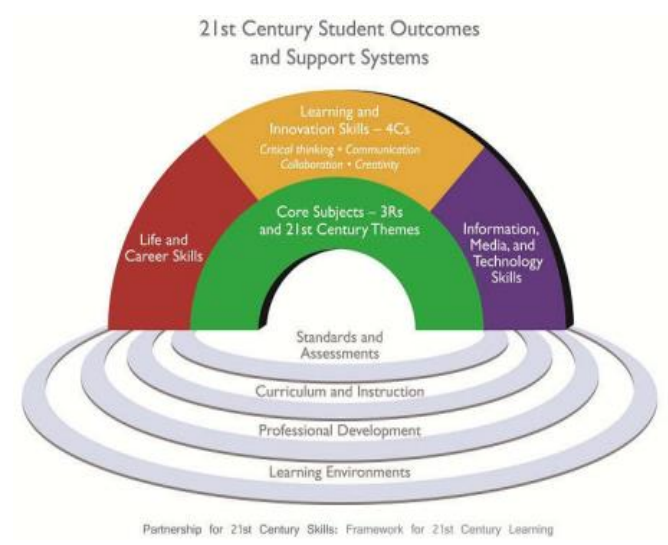

Gambar 1. Framework Pembelajaran Abad ke-21

Sejalan dengan hal itu, Kemdikbud merumuskan bahwa paradigma pembelajaran abad 21 menekankan pada kemampuan mahasiswa dalam mencari tahu dari berbagai sumber, merumuskan permasalahan, berpikir analitis dan kerjasama serta berkolaborasi dalam menyelesaikan masalah (Wijaya et al., 2016). Adapun penjelasan mengenai framework pembelajaran abad ke-21 menurut (Wijaya et al., 2016) adalah sebagai berikut: (a) Kemampuan berpikir kritis dan pemecahan masalah (CriticalThinking and Problem-Solving Skills), mampu berfikir secara kritis, lateral, dan sistemik, terutama dalam konteks 
pemecahan masalah; (b) Kemampuan berkomunikasi dan bekerjasama (Communication and Collaboration Skills), mampu berkomunikasi dan berkolaborasi secara efektif dengan berbagai pihak; (c) Kemampuan berpikir kritis dan pemecahan masalah (CriticalThinking and Problem-Solving Skills), mampu berfikir secara kritis, lateral, dan sistemik, terutama dalam konteks pemecahan masalah; (d) Kemampuan berkomunikasi dan bekerjasama (Communication and Collaboration Skills), mampu berkomunikasi dan berkolaborasi secara efektif dengan berbagai pihak. Khusus 4 kemampuan di atas, dikenal dengan kemmapuan 4C.

Selain kemampuan 4C di atas, juga dilengkapi dengan kemampuan mencipta dan membaharui (Creativity and Innovation Skills), mampu mengembangkan kreativitas yang dimilikinya untuk menghasilkan berbagai terobosan yang inovatif; (f) Literasi teknologi informasi dan komunikasi (Information and Communications Technology Literacy), mampu memanfaatkan teknologi informasi dan komunikasi untuk meningkatkan kinerja dan aktivitas sehari-hari; (g) Kemampuan belajar kontekstual (Contextual Learning Skills), mampu menjalani aktivitas pembelajaran mandiri yang kontekstual sebagai bagian dari pengembangan pribadi, dan (h) Kemampuan informasi dan literasi media, mampu memahami dan menggunakan berbagai media komunikasi untuk menyampaikan beragam gagasan dan melaksanakan aktivitas kolaborasi serta interaksi dengan beragam pihak. Termasuk pihak penyelenggara pendidikan untuk tenaga kependidikan, peningkatan kompetensi terus ditingkatkan dalam pembelajaran abad 21 agar melahirkan generasi digital yang berkualitas (Izzah, 2018).

Guru sebagai pendidik memiliki peran yang besar dalam memberikan kontribusi keberhasilan peserta didiknya. Seorang guru dapat dikatakan telah memberikan pendidikan dan pembelajaran jika terjadi perubahan dalam perilaku peserta didiknya ke arah yang lebih baik. Pengetahuan yang dimiliki peserta didikpun turut menyertai dari yang belum tahu menjadi tahu, dari yang belum mengerti menjadi mengerti. Selain itu, hal penting yang perlu dijasikan perhatian bagi pendidik adalah tahapan evaluasi pembelajaran sehingga feed back yang dihasilkan tepat sasaran. Pendidik dituntut untuk menciptakan suasana belajar yang efektif, inovatif dan menyengakan. Berdasarkan hal tersebut perencanaan pemeblajaran menjadi amat penting untuk dilakukan pendidik agar komponen pembelajaran dapat terorganisir dengan baik.

Pembaharuan dalam model pembelajaran saat ini dibutuhkan agar peserta didik dapat berperan aktif dalam proses pembelajaran. E-test atau electronic test merupakan bagian dari pembelajaran berbasis online yang mana dalam sistem ini akan membantu peserta didik untuk belajar dan mengerjakan latihan soal secara online sehingga menghasilkan nilai yang diharapkan. Adapun platform penggunaan e-test yaitu dengan memanfaatkan aplikasi "that quiz". Melalui penggunaan "that quiz" guru dapat membuat account untuk menyajikan materi maupun soal-soal latihan yang dapat diintegrasikan sebagai bahan evaluasi di akhir pembelajaran. Dengan adanya sistem $e$ test "that quiz" ini peserta didik akan lebih aktif belajar dan menarik minat peserta didik.

Berdasarkan hasil penelitian yang dilakukan Lestari (2016) terdapat perbedaan motivasi belajar kimia siswa kelas eksperimen dan kelas kontrol 
dengan nilai signifikan $\mathrm{p}=0,026$. (b) terdapat perbedaan prestasi belajar kimia antara kelas kontrol dan kelas eksperimen dengan nilai Fhitung $(4,259)>$ Ftabel $(4,034), \mathrm{p}=0,044$, hal ini menunjukan bawah motivasi dan hasil belajar siswa lebih baik dibandingkan pembelajaran yang tidak menggunakan quiz terlebih dahulu. Hal ini memberikan data bahwa siswa akan termotivasi belajar jika peserta didik mengetahui akan diberikan kuis. Permasalahan yang muncuk dalam pelaksanaan tes online bukan hanya sebatas kompetensi dalam mengerjakan tes online, tetapi berkaitan nuga dengan kompetensi pembuat soal tes tersebut. Guru harus memahami esensi dari tes online tersebut. Efektifitas tes online tersebut katena dengan cepat mengetahui kemampuan peserta didik dan segera memberikan evaluasi dari nilai yang didapat. Dari sisi siswa, sebenarnya sudah tidak masalah lagi dengan tes online, karena mereka sehari-hari sudah akrab dengan internet, games online, dan sosial media (Alifiani et al., 2017). Idealnya peserta didik dapat menjalankan aktivitas belajarnya akan memberikan dampak pada hasil belajarnya. Hal ini sejalan dengan paparan (Saputra \& Lisiswanti, 2015) menunjukkan bahwa ada beberapa faktor yang mempengaruhi keberhasilan dalam pembelajaran peserta didik, yaitu kegiatan pengajaran dalam hal ini termasuk pengayaan metode pembelajaran.

Berdasarkan hasil analisis situasi di Sekolah Indonesia (SIB) KBRI Bangkok yang dilakukan pada bulan Agustus 2019. Hasil yang dapatkan dalam kegiatan tersebut berdasarkan pengamatan menunjukkan bahwa masih ditemukan adanya beberapa guru yang masih memerlukan pembaharuan tentang pembelajaran berbasis teknologi informasi, sekitar $45 \%$ peserta didik kurang aktif dalam pembelajaran sehingga didominasi oleh peserta didik yang pintar saja. Guru kelas I sampai dengan kelas VI belum sepenuhnya memanfaatkan internet sebagai bahan ajar dan instrumen penilaian. Lebih dari $90 \%$ guru menggunakan bahan ajar/media visual atau benda tiruan. Guru belum pernah membuat perangkat penilaian berbasis online. Berdasarkan paparan tersebut, maka diperlukan suatu upaya untuk memberikan inovasi dalam meningkatkan kualitas pembelajaran melalui pemanfaatan internet of things sebagai sumebr belajar sekaligus alat evaluasi secara online dengan menggunakan aplikasi that quiz.

Kompetensi profesionalisme guru bukan hanya terkait mendidik, mengajar, membimbing dan menilai saja, tetapi juga meliputi ompetensi secara berkelanjutan yang meliputi pengembangan diri, publikasi ilmiah, dan karya inovatif (Widodo, 2013). Bentuk pengembangan online quiz seperti ini merupakan salah satu pengembangan kompetensi yang berkelanjutan dalam aspek penilaian dengan memanfaatan IPTEKS dalam penyusunannya.

Dalam proses pembelajaran, evaluasi merupakan bagian yang amat penting. Evaluasi dapat memberi gambaran tentang tingkat penguasaan siswa terhadap satu materi, memberi gambaran tentang kesulitan belajar siswa, dan memberi gambaran tentang posisi siswa di antara kawan kawannya. Evaluasi manual dengan instrumen evaluasi memiliki banyak kelemahan. Pertama, evaluasi manual memerlukan waktu dan biaya yang cukupbanyak untuk memproduksi instrumennya. Kedua, pemilihan butir tes dari bank soal cukup merepotkan, baik dalam pemilihan maupun dalam memproduksinya. Ketiga, proses pemeriksaan evaluasi dengan instrumen tercetak cukup rumit, sehingga memerlukan waktu banyak dan cenderung membosankan. Keempat, 
proses pengolahan skor dan pemberian umpan balik kepada responden juga rumit, memerlukan banyak waktu dan juga tidakjarang membosankan. Kelima, secara psikologis evaluasi manual sering menimbulkan kecemasan pada peserta tes. Pengawas yang berada di sekitar mereka, kondisi peserta tes yang lain, serta kondisilingkungan sekitar sering membuat pesertates me-rasa cemas.

Evaluasi merupakan bagian yangamat penting dalam proses pembelajaran. Evaluasi manual dengan instrumen evaluasi tercetak memiliki beberapa kelemahan antara lain : (1) memerlukan waktu dan biaya yang cukup banyak untuk memproduksi instrumen, (2) memerlukan waktu yang cukup banyak untuk proses pengskoran dan pengolahan skor, (3) memerlukan waktu yang cukup banyak untuk pemberian umpan balik kepada responden, dan (4) secara psikologis evaluasi manual sering menimbulkankecemasan pada peserta tes. Kondisi di atas sangat mendesak untuk diatasi. Suatu mekanisme evaluasi perlu diciptakan untuk menanggulangi kelemahan-kelemahan di atas.

Penggunaan komputer saat ini sudah menjadi peralatan multimedia, bahkan hipermedia. Menggunakan perpaduan berbagai teknologi, komputer mempunyai fasilitas hiperteks. Evaluasi menggunakan perangkat digital semacam ini akan mengomputerasisasikan berbagai hal, yaitu a) tes adaptif terkom-puterisasi, b) bank soal, c) desain tes otomatis, d)sistem penulisan butir tes, dan e) tes multimedia. Tes hasil belajar (Achievement test) adalah tesyang digunakan untuk mengukur kemampuan individu dalam satu bidang atau bidang tertentu.Tes hasil belajar ada dua jenis, yaitu: 1) test standaratau test baku, yaitu test yang dipublikasikan dantelah disiapkan oleh para ahli secara cermat sertamencakup tujuan akademis yang lazim bagi sekolah-sekolah pada umumnya, dan 2) test buatan guruadalah test yang disusun oleh guru berdasarkantaksonomi yang ingin diukur dari unjuk kerja indi-vidu setelah mempelajari sesuatu (Setemen, 2010).

\section{METODE}

Penelitian yang dilakukan pada semester ganjil 2019/2020 di SD Sekolah Indonesia Bangkok (SIB) di kelas III, dengan jumlah 5 siswa. Jenis penelitian ini adalah penelitian kualitatif dengan mendeskripsikan secara mendalam. Pada penelitian ini yang bermaksud mendeskripsikan terkait situasi-situasi atau kejadian-kejadian sesuai dengan keadaan lapangan. Pengumpulan data pada penelitian ini dilakukan dengan teknik observasi, wawancara dan dokumentasi. Observasi dilakukan untuk mengumpulkan data tentang praktik pembelajaran yang dilakukan guru, dan kompetensi guru dalam menerapkan that quiz.

Wawancara dilakukan kepada guru yang mempraktikkan pembelajaran tematik dengan menggunakan that quiz. Kuesioner atau angket dilakukan untuk mengumpulkan data tentang kompetensi dan respon guru dalam pembelajaran menggunakan that quiz. Dokumentasi dilakukan untuk mengumpulkan data tentang berbagai peristiwa dalam proses pembelajaran melalui foto, dokumen berupa akun kuis online yang digunakan guru.

Instrumen yang digunakan dalam penelitian antara lain pedoman observasi dengan indikator sebagai berikut. 
Tabel 1. Komponen pembelajaran

\begin{tabular}{|c|c|}
\hline $\begin{array}{c}\text { Komponen } \\
\text { Pembelajaran }\end{array}$ & Indikator \\
\hline Perencanaan & $\begin{array}{l}\text { Kelengkapan } \\
\text { sdministrasi } \\
\text { pembelajaran } \\
\text { Kegiatan awal } \\
\text { Kegiatan inti } \\
\text { Kegiatan akhir } \\
\text { Kisi kisi soal } \\
\text { Bentuk tes }\end{array}$ \\
\hline Pelaksanaan & $\begin{array}{l}\text { Model yang digunakan } \\
\text { Metode yang } \\
\text { diterapkan }\end{array}$ \\
\hline Evaluasi & $\begin{array}{l}\text { Teknik evaluasi } \\
\text { Jenis evaluasi } \\
\text { Refleksi dan tindak } \\
\text { lanjut }\end{array}$ \\
\hline
\end{tabular}

\section{HASIL DAN PEMBAHASAN}

Hasil penelitian menunjukkan bahwa tes merupakan teknik yang digunakan dalam rangka kegiatan pengukuran. Dalam kegiatan tersebut terdapat berbagai pertanyaan yang dikerjakan oleh peserta didik. Hal ini sejalan bahwa tes merupakan kegiatan dalam rangka pengukuran yang di dalamnya terdapat berbagai pertanyaan atau serangkaian tugas yang harus dikerjakan atau dijawab oleh siswa untuk mengukur aspek perilaku siswa.

Hasil pembelajaran yang dilaksanakan oleh guru model dalam pembelajaran 1 dan pembelajaran 2, dapat disimpulkan bahwa pada pembelajaran dilakukan melalui 3 tahap yaitu perencanaan, pelaksanaan atau implementasi, serta penilaian dan evaluasi pembelajaran. Adapun pembahasan tiap tahap kegiatan pembelajaran baik pembelajaran 1 dan pembelajaran 2 dapat dijelaskan sebagai berikut.

a. Perencanaan

Keberhasilan peserta didik dalam pembelajaran menjadi tujuan utama. Sebelum memulai setiap kegiatan setiap orang pasti memiliki perencanaan. Hal itu karena dengan perencanaan kegiatan yang akan dilakukan oleh seseorang akan berjalan dengan baik. Tanpa perencanaan kegiatan yang harusnya dapat dilakukan dengan baik dapat berubah menjadi berantakan karena kita tidak memiliki gambaran dan managemen tentang kegiatan yang akan dilakukan. Dalam kegiatan pembelajaran peran guru dalam merencanakan kegiatan pembelajaran adalah sebuah hal yang wajib dilakukan demi suksesnya pembelajaran yang akan dilakukan.

Perencanaan pembelajaran disusun secara sistematis akan memberikan dampak dalam pelaksanaan pembelajaran yang dilakukan oleh guru. Dengan adanya perencaan tersebut maka efisiensi waktu akan terlaksana dengan baik. Hasil yang diperoleh dapat diprediksi, sehingga kemungkinan kemungkinan yang muncul dalam pembelajaran dapat teratasi. Dokumen rasional yang disusun dalam pembelajaran ini sebagai acuan dalam pelaksanaan pembelajaran. Oleh karena itu, penyususunan perencanaan pembelajaran harus dilakukan oleh guru. Hal ini sependapat dengan paparan (Nadlir, 2013) bahwa guru tidak akan dapat mengajar dengan optimal jika persiapan yang dikembangkan belum selesai.

Perencanaan pembelajaran merupakan sesuai hal yang sangat penting dalam upaya pelaksanaan pembelajaran yang optimal. Perencanaan pembelajaran yang dilakukan guru meliputi persiapan pembelajaran, pelaksnaaan dan evaluasi pembelajaran. Perencanaan berarti menyusun langkah-langkah penyelesaian kegiatan yang terarah dengan tujuan mencapai tujuan tertentu. Dalam perencanaan ini guru membuat akun kuis online menggunakan that quiz. 
Perencanaan yang disusun dalam evaluasi pembelajaran ini adalah menggunakan aplikasi that quiz. Keberhasilan proses pembelajaran dapat diukur melalui keberhasilan peserta didik yang mengikuti kegiatan pembelajaran tersebut. Keberhasilan itu dapat dilihat dari tingkat pemahaman, penguasaan materi serta hasil belajar siswa. Semakin tinggi tingkat pemahaman maka semakin tinggi pula tingkat keberhasilan pembelajaran. Penyajian materi yang kurang tepat juga dapat menjadikan proses pelajaran membosankan.

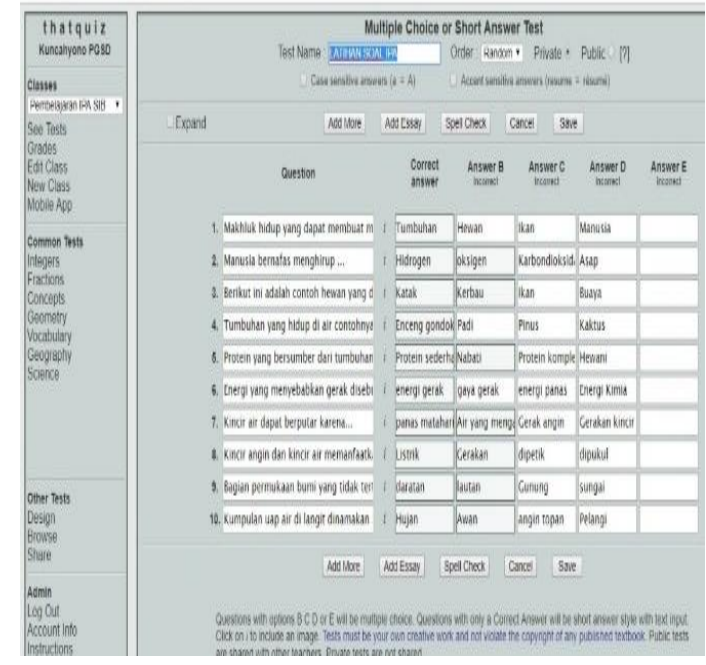

Gambar 2. Akun kuis online that quiz.

Tempat masuk atau login khusus hanya untuk guru, seorang siswa tidak akan punya alasan untuk login karena fitur yang disediakan hanya untuk membantu guru, sedangkan siswa hanya akan mendapatkan kode tes dari guru yang bisa diisikan di tempat test code untuk melakukan tes atau siswa dapat membuka soal-soal yang sudah disediakan oleh situs tersebut dengan mengeklik materi yang telah disediakan (Passy, 2011).

Diantara salah satu langkah yang harus dilakukan seorang pendidik yaitu menyusun perencanaan pembelajaran, yaitu kegiatan yang terus menerus dan menyeluruh, dimulai dari penyusunan suatu rencana, evaluasi pelaksanaan dan hasil yang dicapai dari tujuan yang sudah ditetapkan. Perencanaan pembelajaran adalah memproyeksikan tindakan apa yang akan dilaksanakan dalam suatu pembelajaran menurut Sujana dalam (Djoehaeni, 2009: 5) Hal ini berguna untuk memperoleh kemajuan dalam perkembangan dan belajar peserta didik. Selain itu, Guru dapat memahami peranannya dan tugas-tugas yang harus dicapai oleh peserta didik sehinga proses pembelajaran akan berjalan sesuai dengan apa yang diharapakan.

Perencanaan pembelajaran juga memperhatikan peran karakter. Perencanaan pembelajaran berbasis karakter merupakan model perencanaan dalam pembelajaran yang mengedepankan aspek penanaman nilai-nilai karakter (Nadlir, 2013).

Perencanaan pembelajaran merupakan kegiatan merumuskan tujuan apa yang akan dicapai oleh suatu kegiatan pembelajaran, cara apa yang dipakai untuk menilai pencapaian tujuan tersebut, materi apa yang akan disampaikan, bagaimana cara menyampaikan, serta alat atau media apa yang diperlukan. Pendapat lain mengenai perencanaan pembelajaran adalah kegiatan memproyeksikan tindakan apa yang akan dilaksanakan dalam suatu pembelajaran (PBM) yaitu dengan mengkoordinasikan (mengatur dan merespon) komponen-komponen pembelajaran sehingga arah kegiatan (tujuan), isi kegiatan (materi), cara penyampaian kegiatan (metode dan teknik), serta bagaimana mengukurnya (evaluasi) menjadi jelas dan sistematis.

Perencanaan penting untuk pembelajaran di Sekolah Dasar karena memungkinkan siswa diberi 
kesempatan terbaik untuk memperoleh kemajuan dalam perkembangan dan belajar. (Sholeh, 2007) Perencanaan merupakan fungsi utama yang mempengaruhi fungsi-fungsi berikutnya, sehingga seorang guru harus mampu menyusun perencanaan secara tertulis. Kemampuan guru menuangkan perencanaan pembelajaran dalam bentuk silabus dan RPP sangat penting karena perencanaan pembelajaran juga perlu mendapat evaluasi. Guru dapat memahami peranannya dan tugas-tugas yang harus dicapai siswa untuk berkembang dan belajar. Guru menyediakan sumber sumber belajar untuk mendukung proses belajar.

Perencanaan adalah proses penetapan dan pemanfaatan sumber daya secara terpadu yang diharapkan dapat menunjang kegiatan-kegiatan dan upaya-upaya yang akan dilaksanakan secara efisien dan efektif dalam mencapai tujuan. Dalam hai ini Roger A. Kaufman dalam (Bachri, 2010) mengemukakan bahwa "Perencanaan adalah proyeksi (perkiraan) tentang apa yang diperlukan dalam rangka mencapai tujuan asbah dan nilai. Perencanaan sering juga disebut sebagai jembatan yang menghubungkan kesenjangan atau jurang antara keadaan masa kini dan keadaan yang diharapkan terjadi pada masa yang akan datang.

Perencanaan berkaitan dengan penentuan apa yang akan dilakukan. Perencanaan mendahului pelaksanaan, mengingat perencanaan merupakan suatu proses untuk menentukan kemana harus pergi dan mengidentifikasikan persyaratan yang diperlukan dengan cara yang paling efektif dan efisien.

RPP yang dibuat oleh tim peneliti dibuat selengkap mungkin untuk memudahkan guru dan siswa dalam belajar, selain itu agar tujuan pembelajaran dapat dicapai dengan maksimal. Hal ini sesuai dengan pendapat ahli, menurut pendapat Trianto (2007: 71), rencana pelaksanaan pembelajaran yaitu panduan langkahlangkah yang akan dilakukan oleh guru dalam kegiatan pembelajaran yang disusun dalam skenario pembelajaran. RPP disusun untuk setiap pertemuan yang menjadi pedoman guru dalam pembelajaran. Berdasarkan Peraturan Menteri Pendidikan dan Kebudayaan No. 22 Tahun 2016 tentang Standar Proses Pendidikan Dasar dan Menengah disebutkan bahwa Rencana Pelaksanaan Pembelajaran (RPP) adalah rencana kegiatan pembelajaran tatap muka untuk satu pertemuan atau lebih. RPP dikembangkan dari silabus untuk mengarahkan kegiatan pembelajaran siswa dalam upaya mencapai Kompetensi Dasar (KD). RPP disusun berdasarkan $\mathrm{KD}$ atau subtema yang dilaksanakan tiap kali pertemuan atau lebih.

\section{b. Pelaksanaan}

Perencanaan pembelajaran yang disusun oleh guru dalam suatu kelas akan dilaksanakan dalam pembelajaran sesuai dengan perencanaan tersebut. Pelaksaan that quiz ini mengacu pada pembelajaran tematik. Pembelajaran yang beranjak dari suatu tema tertentu ebagai pusat perhatian (Point of interest) yang digunakan untuk memahami gejala-gejala dan konsep lain, baik yang berasal dari mata pelajaran yang bersangkutan maupun dari mata pelajaran lainnya (Hernawan \& Resmini, 2014).

Pembelajaran 1 dan pembelajaran 2 yang dilakukan oleh guru model di kelas IV SD Sekolah Indonesia Bangkok Thailand, dilakukan tidak hanya di dalam kelas namun juga di luar kelas. Hal ini bertujuan agar pembelajaran memnafaatkan 
lingkungan sekitar siswa, sehingga dari siswa dekat dengan lingkungan serta memberikan pemahaman kepada siswa bahwa belajar tidak harus selalu di dalam kelas, bisa memamfaatkan lingkungan sekitar juga. Berdasarkan hasil penelitian (Neka, dkk 2015) Terdapat perbedaan keterampilan berpikir kreatif dan penguasaan konsep IPA antara siswa yang belajar dengan model pembelajaran inkuiri terbimbing berbasis lingkungan dengan siswa yang belajar dengan model pembelajaran langsung; 2) Terdapat perbedaan keterampilan berpikir kreatif antara siswa yang belajar dengan model pembelajaran inkuiri terbimbing berbasis lingkungan dengan siswa yang belajar dengan model pembelajaran langsung; 3) Terdapat perbedaan penguasaan konsep IPA antara siswa yang belajar dengan model pembelajaran inkuiri terbimbing berbasis lingkungan dengan siswa yang belajar dengan model pembelajaran langsung. Hal tersebut sesuai dengan UU nomor 20 tahun 2003 tentang sistem pendidikan nasional, definisi "pembelajaran adalah proses interaksi peserta didik dengan pendidik dan sumber belajar pada suatu lingkungan belajar". Konsep pembelajaran menurut Corey (dalam Sagala, 2010:61) adalah suatu proses dimana lingkungan seseorang secara disengaja dikelola untuk memungkinkan ia turut serta dalam tingkah laku tertentu dalam kondisi-kondisi khusus atau menghasilkan respons terhadap situasi tertentu. Sedangkan Dimyati \& Mudjiono (2006:297) menuliskan bahwa pembelajaran adalah kegiatan guru secara terprogram dalam desain instruksional, untuk membuat siswa belajar secara aktif yang menekankan pada penyediaan sumber belajar.

Ashim (2019) menekankan bahwa melalui pembelajaran berbasis mobile learning dan penguasaan komunikasi matematika harapannya mampu menciptakan kualitas pendidikan yang lebih baik, guru dan siswa mampu mengikuti perkembangan teknologi, serta mampu meningkatkan kemampuan 4C di Era Disrupsi. Berdasarkan hasil penelitian yang sudah dipaparkan, diketahui bahwa dalam pembelajaran yang dilakukan oleh guru model menggunakan berbagai metode pembelajaran. Metode yang digunakan antara lain metode ceramah, metode diskusi kelompok, metode diskusi kelas, metode penugasan, metode praktikum dan unjuk kerja, dan lain-lain.

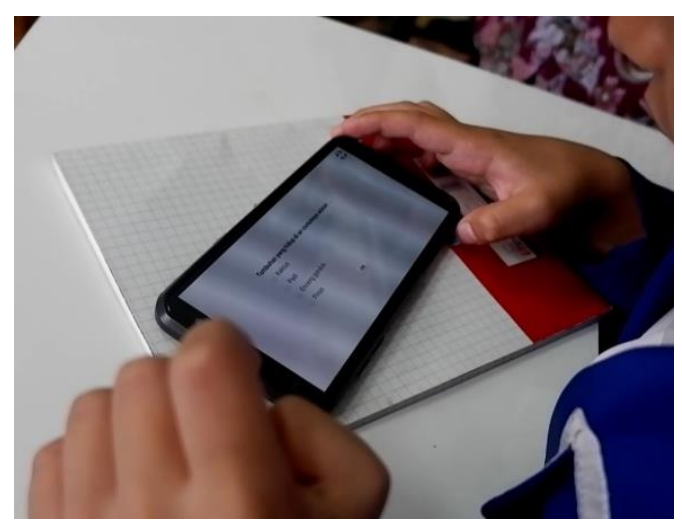

Gambar 3. Implementasi that quiz

Berdasarkan observasi guru model dan observer, diketahui bahwa dengan adanya metode pembelajaran yang bervariasi membuat siswa antusias dalam belajar dan siswa tidak bosan dalam belajar. Hal tersebut diperkuat dengan pendapat (Afandi et al., 2013) mengatakan, metode belajar mengajar adalah cara-cara yang dilakukan untuk menyampaikan atau menanamkan pengetahuan kepada subjek didik, murid, atau anak melaui sebuah kegiatan belajar mengajar, baik di sekolah, rumah, kampus, pondok, dan lain-lain.

Selain menggunakan metode pembelajaran yang bervariasi, guru model juga menggunakan berbagai media pembelajaran yang bervariasi. 
Berdasarkan hasil yang telah dipaparkan diketahui bahwa media yang digunakan oleh guru model pada pembelajaran 1 dan pembelajaran 2 yaitu video, gambar, maupun benda-benda konkret. Media yang bervariasi memungkinkan siswa memiliki pengalaman belajar yang berbeda. Dengan adanya media pembelajaran yang bervariasi juga diharapkan agar siswa mampu mencapai tujuan pembelajaran dengan maksimal. Hal ini sesuai dengan pendapat (Falahudin, 2014) mengatakan bahwa media adalah komponen sumber sumber belajar atau wahana fisik yang mengandung materi instruksional di lingkungan siswa yang dapat merangsang siswa untuk belajar. Sedangkan menurut (Gunawan, 2016) mengatakan media pembelajaran merupakan segala sesuatu yang dapat menyalurkan pesan, dapat merangsang pikiran, perasaan, dan kemauan siswa sehingga dapat mendorong terciptanya proses belajar untuk menambah informasi baru pada diri siswa. Sehingga dapat disimpulkan bahwa media pembelajaran merupakan segala sesuatu.

\section{c. Evaluasi}

Penilaian dan evaluasi pembelajaran perlu dilakukan karena dengan hasil penilaian siswa dapat mengetahui kekurangan dan kelebihannya dalam belajar selama ini. Karena dengan penilaian, menurut Widoyoko (2011: 36-37) manfaat penilaian bagi siswa yaitu siswa dapat mengetahui sejauh mana telah berhasil mengkuti pembelajaran yang disampaikan oleh guru. Hasil yang diperoleh siswa dari penilaian meliputi dua kemungkinan yaitu memuaskan atau tidak memuaskan. Adapun gambaran hasil evaluasi hasil pembelajaran menggunakan kuis online dapat dilihat pada Gambar 4 berikut.

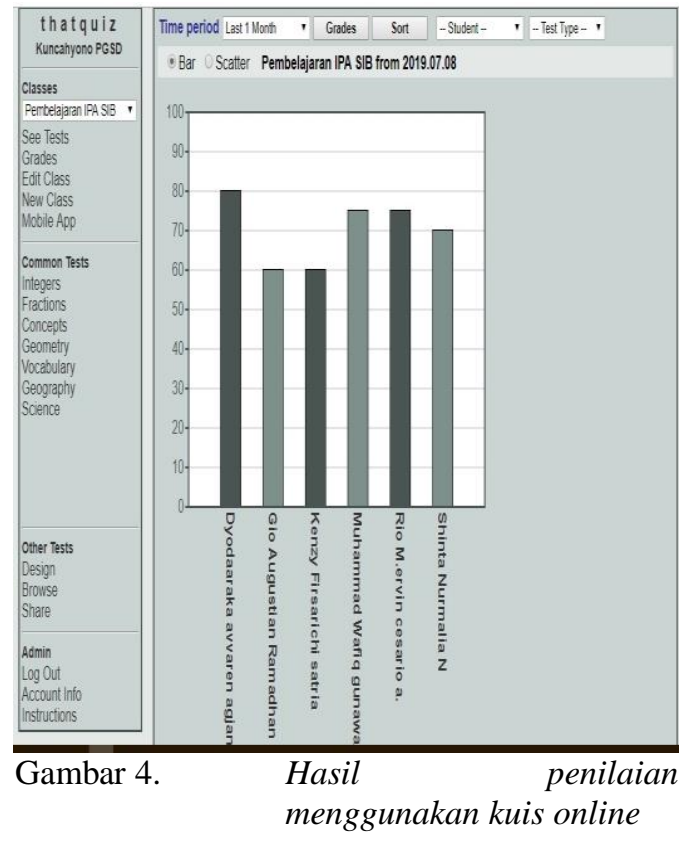

Berdasarkan gambar 4. Tampak bahwa evaluasi hasil pembelajaran menggunakan kuis online lebih mudah dipantau dan lebih praktis. Menurut Gronlund (dalam Purwanto, 2010: 3) evaluasi adalah suatu proses yang sistematis untuk menentukan atau membuat keputusan sejauh mana tujuan-tujuan pembelajaran dicapai oleh siswa. Inti dari kegiatan evaluasi yaitu adanya pengambilan keputusan, dan obyek dari evaluasi yaitu program pembelajaran. Sehingga evaluasi bertujuan untuk mendapatkan informasi tentang efektivitas program pembelajaran. Evaluasi pembelajaran yaitu evaluasi program pengambilan keputusan yang diperoleh dari hasil asesmen terhadap kegiatan belajar siswa yang dilakukan melalui proses pembelajaran. Hasil penelitian (Setemen, 2010) menghasilan sistem evaluasi on-line ini telah berhasil mengembangkan rancang bangun beserta implementasinya. Fungsifungsi yang bisa diakomodasi oleh sistem ini mampu mengelola data mahasiswa, mengelola data soal ujian. 
Sistem evaluasion-line diuji dalam kelompok kecil mahasiswa dan diperoleh hasil bahwa evaluasi online cenderung diterima baik oleh mahasiswa Proses evaluasi pembelajaran akan menjadi lebih baik, lebih demokratis, bila melibatkan rekan staf pendidik yang handal, manajemen sekolah dan pihak orang tua.

Dari evaluasi tersebut akan menghasilkan hasil belajar peserta didik. Menurut (Sapta, 2017) Pemahaman belajar adalah: (1) Belajar adalah perubahan perilaku, yang perubahan itu dapat menyebabkan perilaku yang lebih baik, tetapi juga kemungkinan untuk menyebabkan perilaku yang lebih buruk, (2) Belajar adalah sesuatu perubahan melalui pelatihan atau pengalaman; dalam arti perubahan yang disebabkan oleh pertumbuhan atau kematangan tidak dianggap sebagai hasil belajar; seperti terjadi pada orang perubahanperubahan bayi, (3) Untuk dapat disebut belajar, maka perubahan harus relatif stabil; harus menjadi akhir dari periode waktu yang lama. Beberapa waktu yang lama itu berlangsung sulit untuk menentukan dengan pasti, tetapi perubahan itu harus menjadi akhir dari periode yang bisa berlangsung selama berhari-hari, berbulanbulan atau bertahun-tahun, (4)

Hasil belajar melalui proses blended learning juga memberikan dampak positif terhaddap hasil dan motivasi siswa. Hasil belajar siswa setelah penerapan Blended Learning mengalami peningkatan, persentase ketuntasan belajar sebelum tindakan adalah $30,30 \%$, setelah tindakan siklus 1 adalah $72,73 \%$, dan setelah tindakan siklus 2 adalah 87,88\%. (2) Hasil kegiatan mengajar guru mengalami peningkatan dari siklus 1 dengan jumlah nilai rata-rata 55 dalam kategori cukup dan siklus 2 dengan jumlah nilai rata-rata 68,33 dalam kategori baik. (3)
Hasil kegiatan belajar siswa siklus 1 dengan jumlah nilai rata-rata 26,33 dalam kategori kurang, dan siklus 2 dengan jumlah nilai rata-rata 35 dalam kategori baik. (4) Hasil respon siswa siklus 1 terhadap 33 siswa mendapatkan jumlah nilai 1210, dengan rata-rata 36,67 dalam kategori baik, dan siklus 2 terhadap 31 siswa mendapatkan jumlah nilai 1242, dengan jumlah rata-rata 40,06 dan termasuk dalam kategori sangat baik (Rizkiyah, 2015).

Lebih lanjut hasil penelitian senada terkait hasil belajar dalam pembelajaran e-learning oleh (Yunika, 2017) peningkatan hasil belajar mahasiswa yang diajar dengan menggunakan model Blended Learning lebih tinggi dari mahasiswa yang diajar dengan pembelajaran biasa baik secara keseluruhan maupun berdasarkan level kemampuan awal matematika (tinggi, sedang dan rendah), (2) peningkatan kemandirian belajar mahasiswa yang diajar dengan menggunakan model Blended Learning lebih tinggi dari mahasiswa yang diajar dengan pembelajaran biasa ditinjau dari keseluruhan, level kemampuan awal matematika tinggi dan sedang, namun tidak lebih tinggi pada level rendah.

Berdasarkan hasil penelitian tersebut dapat dikatakan bahwa perilaku mengalami perubahan karena belajar terkait dengan berbagai aspek kepribadian, baik fisik maupun psikis, seperti: perubahan dalam hal memecahkan masalah/berpikir, keterampilan kecakapan, kebiasaan, atau sikap. Menyadari hal tersebut, pembaharuan evaluai dalam pembelajaran dapat menggunatak that quiz sebagai alat untuk mengukur keberhasilan tersebut (Sapta, 2017). 


\section{KESIMPULAN}

Berdasarkan hasil yang sudah dipaparkan maka kesimpulan sebagai berikut: Guru memiliki kompetensi digital skill inovatif dalam menerapkan pembelajaran berbasis komputer dengan ditunjukkan guru mampu membuat akun kuis online. Guru cenderung memanfaatkan sarana dan prasarana yang ada di kelas dengan mengintegrasikan media melalui jaringan internet yang sudah disediakan oleh sekolah sehingga guru lebih mudah mengakses materi maupun jenis media berbasis komputer lainnya.

Pembelajaran sekaligus penilaian berbasis kuis online dilakukan secara daring dengan memanfaatkan internet of things. Guru-guru menghasilkan produk akun quiz online dengan aplikasi open source that quiz. Pelaksanaan pembelajaran yang dilaksanakan guru menggunakan aplikasi that quiz lebih mudah mengakses materi secara ringkas dan cepat dan lebih mudah melaksanakan penilaian dan kontrol siswa secara langsung. Akses pembelajaran dan penilaian dapat dikontrol secara langsung melalui akun masing-masing siswa.

\section{DAFTAR PUSTAKA}

Afandi, M., Chamalah, E., Wardani, O. P., Gunarto, H., \& Hum, M. (2013). Model dan Metode Pembelajaran. Semarang: UNISSULA.

Alifiani, A., Jiwandono, N. R., \& Nursit, I. (2017). Pengembangan Tes Online Menggunakan Thatquiz Pada Bidang Studi Matematika. Jurnal Pendidikan Matematika (JPM), 3(2), 09-21.
Ashim, M., Asikin, M., Kharisudin, I., \& Wardono, W. (2019). Perlunya Komunikasi Matematika dan Mobile Learning Setting Problem Based Learning untuk Meningkatkan Kemampuan 4C di Era Disrupsi. PRISMA, Prosiding Seminar Nasional Matematika, 2, 687-697.

Bachri, B. S. (2010). Implementasi Pengembangan Content Curriculum dalam Proses Perencanaan Pembelajaran. Jurnal Teknologi Pendidikan, 1, 0.

Falahudin, I. (2014). Pemanfaatan media dalam pembelajaran. Jurnal Lingkar Widyaiswara, 1(4), 104117.

Gunawan, A. (2016). Pemanfaatan Teknologi Informasi Dan Komunikasi Melalui Penggunaan Media Pendidikan Dalam Pembelajaran IPS SD. Pedagogi: Jurnal Penelitian Pendidikan, $3(2)$.

Hernawan, A. H., \& Resmini, N. (2014). Pembelajaran Terpadu di SD.

Indonesia, B., \& Study, L. (2017). Proses Pembelajaran Matematika Menggunakan Budaya Indonesia Pada Lesson Study Di Sd Indonesia Bangkok Thailand Erna Yayuk dan Dyah Worowirastri Ekowati menentukan kemajuan bangsa indonesia Indonesia. Di sisi lain, usia anak SD Indonesia KBRI Thailand. . 3, 459-468.

Izzah, I. N. (2018). Pengembangan Media Touch and Play 3D Images Materi Panca Indera Kelas Iv Sekolah Dasar Berbasis Adobe Flash. Florea: Jurnal Biologi Dan Pembelajarannya, 4(2),

39. 
https://doi.org/10.25273/florea.v4 i2. 1812

Nadlir, M. (2013). Perencanaan pembelajaran berbasis karakter. Jurnal Pendidikan Agama Islam (Journal of Islamic Education Studies), 1(2), 338-352.

Pendidikan, K., \& Indonesia, K. R. (2004). Seri Pendidikan Orang Tua: Mendidik Anak di Era Digital, Cet. I. Jakarta: Kementerian Pendidikan Dan Kebudayaan. Naisbitt, John, et. All.

Prestianta, A. M. (2016). Identifikasi Pola Penggunaan Perangkat Bergerak Elektronik Dikalangan Mahasiswa Universitas Multimedia Nusantara. Laporan Hasil Penelitian.

Sapta, A. (2017). Pengaruh Penggunaan Quiz Creator Terhadap Hasil Belajar Matematika Siswa. Jurnal Mathematic PaedagogiC, 1(1), 91-96.

Saputra, O., \& Lisiswanti, R. (2015). Faktor-faktor mempengaruhi keberhasilan pembelajaran keterampilan klinik di Institusi Pendidikan Kedokteran. Juke Unila, 5(9), 104-109.

Setemen, K. (2010). Pengembangan evaluasi pembelajaran online. Jurnal Pendidikan Dan Pengajaran, 43(3).

Sholeh, M. (2007). Perencanaan pembelajaran mata pelajaran geografi tingkat SMA dalam konteks KTSP. Jurnal Geografi: Media Informasi Pengembangan Dan Profesi Kegeografian, 4(2).

Suwandayani, B. I., Soenaryo, S. F., \& Susanti, R. D. (2019). Perencanaan pembelajaran
Creative Learning dalam mata kuliah Profesi Keguruan. Lentera: Jurnal Pendidikan, 14(2), 32-41.

Tarma, T., \& Hasanah, U. (2017). Workshop Parental Control Berbasis Android untuk Mencegah Akses Konten Pornografi pada Anak Usia Sekolah Dasar di Desa Cililin Kecamatan Cililin Kabupaten Bandung Barat. Sarwahita, 14(02), 145-150.

Wijaya, E. Y., Sudjimat, D. A., Nyoto, A., \& Malang, U. N. (2016). Transformasi pendidikan abad 21 sebagai tuntutan pengembangan sumber daya manusia di era global. Prosiding Seminar Nasional Pendidikan Matematika, 1, 263-278.

Yunika, Lestari Ningsih. 2017. Peningkatan Hasil Belajar dan Kemandirian Belajar Metode Statistika Melalui Pembelajaran Blended Learning. Al-Jabar: Jurnal Pendidikan Matematika, Vol 8 (2). 